J. Clin. Chem. Clin. Biochem.

Vol. 26, 1988, pp. 705-713

(C) 1988 Walter de Gruyter \& Co.

Berlin - New York

\title{
Evaluation of a New Chemiluminescence Immunoassay for the Determination of Human Chorionic Gonadotropin in Serum
}

\author{
By P. Luppa, D. Neumeier and M. Knedel \\ Institute of Clinical Chemistry, Klinikum Großhadern, University of Munich
}

(Received June 13/August 24, 1988)

Summary: A new commercially available chemiluminescence immunoassay for the quantitative measurement of human chorionic gonadotropin and its $\beta$-subunit in serum was compared with the enzyme immunoassay used in our routine laboratory.

Human chorionic gonadotropin was determined in serum from pregnant women, as well as from women with abortus imminens, suspected ectopic pregnancies or with molar pregnancies.

The new human chorionic gonadotropin assay was also evaluated in combination with an automatic sample processor for distributing samples to the antibody-coated wells of the microtitre plates.

The analytical precision, specificity and accuracy of the human chorionic gonadotropin assay were assessed with 152 sera, using the $60 \mathrm{~min}$-incubation as well as the shorter $15 \mathrm{~min}$ version. Specificity was comparable with the conventional system, whereas the chemiluminescence assay performed better with respect to the assay detection limit and measuring range.

The enhanced chemiluminescence system for the determination of human chorionic gonadotropin is an efficient assay which agrees well with our routine assay. In connection with an automatic sample processor it enables an advanced and versatile system for the determination of human chorionic gonadotropin in laboratories with large series. The system is rapid, easy to handle and apparently free from interference.

\section{Introduction}

Human chorionic gonadotropin, a glycoprotein composed of two dissimilar subunits ( $\alpha$ and $\beta$ ), is mainly produced by normal and neoplastic trophoblasts (1). There is no known binding protein. In addition to the entire human chorionic gonadotropin molecule the existence of free $\alpha$ - and $\beta$-subunits has been demonstrated $(1-3)$. The determination of human chorionic gonadotropin in serum is of great importance in the monitoring of pregnancies, and in the assessment and management of gestational choriocarcinomas and a variety of testicular germ cell tumours $(2-5)$. It has been proven that the combined use of ultrasound and serial human chorionic gonadotropin determinations gives reliable information for the diagnosis of ectopic pregnancy, a cause of acute gynaecologic emergency in premenopausal women $(6,7)$.
The gynaecological laboratory of our clinical chemistry department averages $10-20$ serum samples per day for the quantitative measurement of human chorionic gonadotropin. This high diagnostic requirement resulted in the replacement of formerly used radioimmunoassay for human chorionic gonadotropin by similar techniques using non-isotopic labels in our unit.

Recently, the development of chemiluminscence immunoassays has led to significant improvements, so that these systems are suitable alternatives for the other immunoassays $(8,9)$.

The coupling of horseradish peroxidase to the antigen or to the antibody in place of the luminescent substrate together with the use of monoclonal antibodies increased sensitivity and specificity in the quantitative 
determination of antigens in biological fluids (10). Furthermore an enhanced luminescence technology by addition of certain aromatic compounds to the signal reagent made this assay format more convenient $(11,12)$.

The Amerlite ${ }^{\circledast}$ system for the measurement of human chorionic gonadotropin in serum represents an enhanced chemiluminescent immunoassay. First presented in 1986 the assay was carried out with monoclonal anitbodies in coated wells with two incubation periods (first $2 \mathrm{~h}$, then $1 \mathrm{~h}$ incubation time) (13). Now an advanced version has been launched with a single $1 \mathrm{~h}$ incubation step.

This article describes the evaluation of this new chemiluminescence assay format with regard to performance criteria; the system is compared with the Enzymun-Test ${ }^{\oplus}$ immunoassay. In combination with the semi-automatic ES-22 processor, the enzyme immunoassay for human chorionic gonadotropin is a complete, proven and practical non-radioactive immunoassay system. Therefore we also checked the possibilities of connecting the Amerlite ${ }^{\circledR}$ system with an automatic sample processor. With specially adapted software programs, the liquid handling processor prepares the way for the integration of this chemiluminescence assay system on-line in our laboratory computer system.

\section{Materials and Methods}

\section{Patients and serum specimens}

Blood samples $(n=152)$ were collected during two months from more than 100 patients treated for threatened or ectopic pregnancies, for abortus imminens, molar pregnancies or choriocarcinomas, and from women, who were being monitored for in-vitro fertilization. After clotting and centrifugation, the sera were stored at $4{ }^{\circ} \mathrm{C}$ until determination of human chorionic gonadotropin in both the immunoassays. Determinations with the enzyme immunoassay showed a proportionate distribution of human chorionic gonadotropin values randomly throughout the concentration range. Pooled sera for the precision studies of the chemiluminescence assay were collected from more than 200 pregnant women and stored in $2 \mathrm{ml}$ aliquots at $-70^{\circ} \mathrm{C}$.

Three external control sera (Lyphocheck ${ }^{\oplus 9}$ immunoassay control sera) were used for the precision studies of the enzyme immunoassay (Bio-Rad Laboratories $\mathrm{GmbH}$, München, F. R.G.). The measurements on the assay detection limit and the recovery studies were performed using the first International Reference Preparation of human chorionic gonadotropin (1st I. R. P. 75/ 537).

\section{Assay and instrumentation characteristics}

The Enzymun-Test ${ }^{\boxplus}$ assay system ES-22 (Boehringer Mannheim, Mannheim, F. R. G.) is a modular batch analyser system for semi-automatic performance of tests including a pipetting and washing unit, photometer, interface and assay-calculator (Epson HX-20 with the program ELISA-22). The enzyme immunoassay for the determination of human chorionic gonadotropin and its $\beta$-subunit in serum comprises two antibodies to human chorionic gonadotropin. One monoclonal antibody is coated to the tubes in which the assay is performed, the second polyclonal one is labeled with peroxidase enzyme. The antibodies form a sandwich complex with hurian chorionic gonadotropin $\beta$-epitopes, the chromogenic substrate for visualizisation of the bound complex is $\mathrm{ABTS}{ }^{\oplus}\left(+\mathrm{H}_{2} \mathrm{O}_{2}\right)$. The measuring range is from 0 to $600 \mathrm{IU} / 1$ human chorionic gonadotropin (1st I. R.P. 72/537), sample volume $200 \mu$, incubation times $3 \times 30$ $\min$ at $25^{\circ} \mathrm{C}$.

The Amerlite ${ }^{\oplus}$ system (Amersham International plc., Bucks, U. K.) consists of a pipettes-workstation, an incubator, a wash station and a luminescence analyser with integrated calculator (software version 4.0). The microtitre wells of the human chorionic gonadotropin-60 assay are coated with a polyclonal sheep antibody to human chorionic gonadotropin, whereas the conjugate reagent contains a monoclonal mouse anti-human chorionic gonadotropin labeled with peroxidase enzyme. The signal reagent consists of luminol as substrate plus enhancer solution. The measuring range is from 0 to $1000 \mathrm{IU} / 1$ human chorionic gonadotropin (1st I. R.P. 75/537), sample volume $50 \mu \mathrm{l}$, and the incubation time $1 \times 60 \mathrm{~min}$ at $37^{\circ} \mathrm{C}$. A short version of the assay format was performed with $1 \times 15 \mathrm{~min}$ only.

Reagent and sample distributions for the chemiluminescence assay were performed manually or by using the TECAN fully automatic sample processor RSP 5402 (Zinsser Analytic GmbH, Frankfurt a.M., F. R. G.) with special software programs (on IBM PS/2) adapted to the human chorionic gonadotropin assay. All liquid handlings from prime rack to microtitre plates were done by the processor with two robotic arms working independently from each other.

\section{Evaluation procedure}

The chemiluminescence assay and the enzyme immunoassay were evaluated according to the recommendations given by Singer et al. (14). The same competent laboratory staff was involved during the entire trial. After an appropriate familiarization period, all determinations were done in duplicate. The Amerlite ${ }^{\circledast}$ human chorionic gonadotropin- 60 kits had the batch number LAN. 0083, lot CH-B:2. We compared the luminescence and enzyme immunoassays with 152 consecutive sera. The short version of the chemiluminescence assay was compared with the $60 \mathrm{~min}$ version using 62 sera.

To ascertain the analytical detection limit of the chemiluminescence assay we calculated the detection limit as the human chorionic gonadotropin value corresponding to the mean plus $3 \times$ standard deviation of the zero light intensity, measured 5 times in duplicate in separate assays.

To check the specificity of the two-site enhanced chemiluminescence assay we used 5 separate sera with high hypophyseal gonadotropin contents. To check non-specific interferences we analysed several haemolysed and lipaemic sera as well as $\mathbf{4}$ sera with known monoclonal hyperimmunoglobulinaemia. Linearity of sample dilutions, an essential attribute of perfected human chorionic gonadotropin kits, was tested by diluting 2 high human chorionic gonadotropin sera consecutively; the measured light intensities were compared with the corresponding ones of the standard samples series. The recovery, another assessment of assay inaccuracy, was determined by measuring the human chorionic gonadotropin concentrations following the addition of known amounts of 1 st I:R.P. standard to 2 sera with low human chorionic gonadotropin contents. 


\section{Results}

Performance characteristics of the enhanced chemiluminescence immunoassay for human chorionic gonadotropin

\section{Calibration}

The two-site chemiluminescence assay produces a standard curve up to a human chorionic gonadotropin concentration of $1000 \mathrm{IU} / 1$ in the typical shape of the immunometric test principle. The analyser uses a nonlinear least squares regression technique to fit curves and prints out a light index, which indicates whether the light intensities obtained fall within the expected range. Between 2 and 20 minutes after adding signal reagent only minor dependences on the time of measuring the standard curve can be seen (about 1-2\% differences for the highest light intensities of the standards).

The chemiluminescence test kit contains 6 standards based on serum, 3 kit control sera and 1 special high sample diluent (see under "Detection limit").

\section{Precision}

Over the entire measuring range all mean coefficients of variation $(\mathrm{CV})$ clearly show a good precision of

Tab. 1. Reproducibility data for within- and between-series precision for the chemiluminescence and the enzyme immunoassay

Chemiluminescence assay

Within-series kit control 1 kit control 2 pool serum precision

\begin{tabular}{lccc}
\hline $\bar{x}(I U / 1)$ & 12.7 & 271 & 745 \\
$\mathrm{CV}(\%)$ & 4.5 & 2.7 & 1.5 \\
$\mathrm{~N}$ & 10 & 10 & 10
\end{tabular}

Between-series pool serum 1 pool serum 2 pool serum 3 precision

\begin{tabular}{lccc}
\hline$\overline{\bar{x}}(\mathrm{IU} / 1)$ & 30.5 & 183 & 43950 \\
$\mathrm{CV}(\%)$ & $6 . \overline{7}$ & 4.1 & 4.0 \\
$\mathrm{~N}$ & 10 & 10 & 10
\end{tabular}

Enzyme immuñoassay

\begin{tabular}{llcc}
$\begin{array}{l}\text { Within-series } \\
\text { precision }\end{array}$ & $\begin{array}{c}\text { contrọl } \\
\text { serum 1 }\end{array}$ & $\begin{array}{c}\text { control } \\
\text { serum 3 }\end{array}$ & pool serum \\
\hline$\overline{\mathrm{x}}(\mathrm{IU} / \mathrm{l})$ & 15.4 & 92.0 & 158 \\
$\mathrm{CV}(\%)$ & 5.4 & 4.1 & 2.7 \\
$\mathrm{~N}$ & 10 & 10 & 5 \\
Between-series & control & pool serum 1 & pool serum 2 \\
precision & serum 1 & & \\
\hline$\overline{\mathrm{x}}(\mathrm{IU} / \mathrm{l})$ & 62.5 & 190 & 382 \\
$\mathrm{CV}(\%)$ & 8.1 & 3.5 & 4.7 \\
$\mathrm{~N}$ & 31 & 31 & 31 \\
\hline
\end{tabular}

the chemiluminescence assay with values between 1.5 and $4.5 \%$ in the intra-assay protocol and between 4.0 and $6.7 \%$ in the inter-assay study (see tab. 1). These results are comparable with the CV's of the enzyme immunoassay used in routine, which are also shown in table 1.

The short 15 min version has a lower precision, but the between-series precision is still satisfactory: CV $=6.3 \%$ at a mean value $(\overline{\mathrm{x}})$ of $30.9 \mathrm{IU} / \mathrm{l}(\mathrm{N}=6)$ and $\mathrm{CV}=8.5 \%$ at a $\overline{\mathrm{x}}$ of $41500 \mathrm{U}^{\prime} /(\mathrm{N}=6)$.

\section{Detection limit}

The threshold for detection of human chorionic gonadotropin was calculated as the human chorionic gonadotropin value corresponding to the mean plus $3 \times \mathrm{SD}$ of the zero light intensity (14). The highest light intensities of the zero standard concentration showed $\overline{\mathrm{x}}=0.06 \%$, standard deviation (SD) $=0.03$ $(\mathrm{N}=5)$; the detection threshold was $0.15 \%$ of the highest light intensity, equivalent to $1.25 \mathrm{IU} / 1$ human chorionic gonadotropin. To document the assay imprecision in the low analytical range (15), repeated measurements of 7 specimens of the I. R.P., prepared by diluting the 75/537 reference preparation with high sample diluent purchased from Amersham (modified TRIS buffer, $50 \mathrm{mmol} / \mathrm{l}$ ), were performed with the human chorionic gonadotropin- 60 assay. The theoretical values for these specimens were $10.0 ; 7.5 ; 5.0$; $2.5 ; 1.25 ; 1.00$ and $0.625 \mathrm{IU} / 1$. Each sample was assayed in duplicate in 7 separate runs on different days.

Table 2 summarizes the various values for the assay variability. The standard deviations in the low concentration range were nearly constant. Even at the calculated detection limit $(1.25 \mathrm{IU} / \mathrm{l})$ the measured

Tab. 2. Assay variabilities of the chemiluminescence assay determined by repeated measurements of diluted $1 \mathrm{st}$ I. R.P. in relation to the detection threshold

\begin{tabular}{|c|c|c|c|c|c|c|c|}
\hline $\begin{array}{l}\text { Human } \\
\text { chorionic } \\
\text { gonadotropin } \\
\text { (IU/l) } \\
\text { calculated } \\
\text { (diluted } \\
\text { I. R.P.) }\end{array}$ & 10.0 & 7.5 & 5.0 & 2.5 & 1.25 & 1.0 & 0.625 \\
\hline $\begin{array}{l}\text { Human } \\
\text { chorionic } \\
\text { gonadotropin } \\
\text { (IU/1) } \\
\text { measured } \\
(\mathrm{N}=6 / 7)\end{array}$ & $\begin{array}{r}10.3 \\
9.9 \\
10.4 \\
10.2 \\
9.8 \\
9.9 \\
-\end{array}$ & $\begin{array}{l}6.3 \\
6.7 \\
7.4 \\
7.5 \\
7.1 \\
7.1 \\
-\end{array}$ & $\begin{array}{l}5.1 \\
3.8 \\
4.3 \\
5.1 \\
4.5 \\
4.5 \\
-\end{array}$ & $\begin{array}{l}2.1 \\
1.7 \\
2.3 \\
2.1 \\
2.5 \\
1.6 \\
2.5\end{array}$ & $\begin{array}{l}0.8 \\
0.8 \\
1.6 \\
1.2 \\
1.3 \\
0.8 \\
1.2\end{array}$ & $\begin{array}{l}0.5 \\
0.8 \\
1.1 \\
1.0 \\
0.9 \\
0.5 \\
1.1\end{array}$ & $\begin{array}{l}0.3 \\
0.0 \\
0.6 \\
0.6 \\
0.5 \\
0.4 \\
0.7\end{array}$ \\
\hline $\begin{array}{l}\overline{\mathbf{x}}(\mathrm{IU} / \mathrm{l}) \\
\mathrm{SD}\end{array}$ & $\begin{array}{r}10.08 \\
0.25\end{array}$ & $\begin{array}{l}7.00 \\
0.45\end{array}$ & $\begin{array}{l}4.55 \\
0.50\end{array}$ & $\begin{array}{l}2.11 \\
0.36\end{array}$ & $\begin{array}{l}1.10 \\
0.31\end{array}$ & $\begin{array}{l}0.84 \\
0.26\end{array}$ & $\begin{array}{l}0.44 \\
0.24\end{array}$ \\
\hline
\end{tabular}




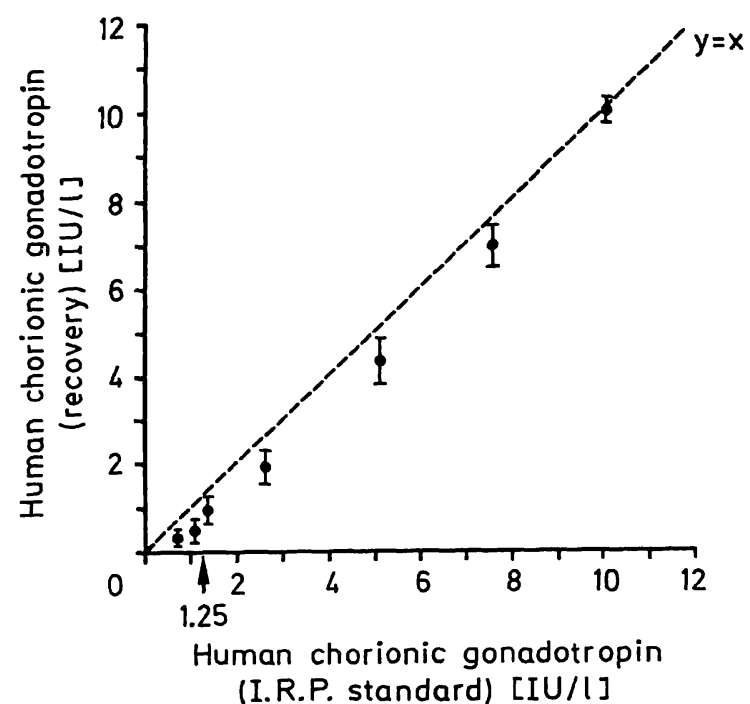

Fig. 1. Determination of assay variabilities and recoveries of the chemiluminescence assay at the low end detection limit by measuring diluted 1st I. R.P. Mean values $\pm S D$

concentration of the corresponding I. R.P. dilution $(1.25 \mathrm{IU} / \mathrm{l})$ varied between 0.8 and $1.4 \mathrm{IU} / \mathrm{l}$, which did not overlap the next higher I. R.P. dilution ( 2.5 IU/l). This can be seen from the figure 1 .

\section{Linearity of dilutions}

Since the human chorionic gonadotropin concentrations have a wide range, up to more than $100000 \mathrm{IU} / 1$ in the serum of pregnant women, special attention must be paid to the linearity of serum dilutions.

To test this, two sera with 800 and $1100 \mathrm{IU} / 1$ human chorionic gonadotropin were diluted successively with diluent and the measured light intensities were plotted versus the resulting human chorionic gonadotropin values. In figure 2 the results of one serum dilution

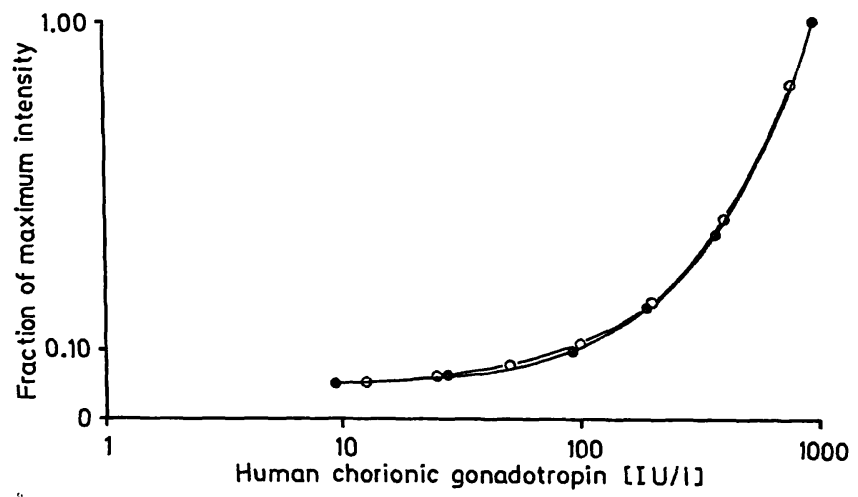

Fig. 2. Linearity of the chemiluminescence assay checked by serial dilution of serum with $800 \mathrm{IU} / 1$ human chorionic gonadotropin

$0-0$ serum dilution

- - - standard curve (serum with $800 \mathrm{IU} / 1$ human chorionic gonadotropin) are shown in relation to the standard curve. One can see that the linearity of dilutions is good up to the detection limit of the chemiluminescence assay.

\section{Recovery studies}

Two serum specimens were spiked with the 1st I.R.P. human chorionic gonadotropin standard (dissolved in high sample diluent) at three levels. The mean recovery of $86 \%$ for the enhanced luminescence assay is comparable with the recoveries $(\overline{\mathrm{x}}=90 \%)$ found in serum $\mathrm{B}$ for the enzyme immunoassay. Results are given in table 3.

Tab. 3. Recovery study for the chemiluminescence and the enzyme immunoassay

\begin{tabular}{llll}
\hline $\begin{array}{l}\text { Initial } \\
\text { human } \\
\text { chorionic } \\
\text { gonadotropin } \\
\text { concentration } \\
\text { (IU/1) }\end{array}$ & $\begin{array}{l}\text { Human } \\
\text { chorionic } \\
\text { gonadotropin } \\
\text { concentration } \\
\text { expected (IU/1) } \\
\text { (I. R.P. } \\
\text { standard) } \\
\text { added) }\end{array}$ & $\begin{array}{l}\text { Human } \\
\text { chorionic } \\
\text { gonadotropin } \\
\text { concentration } \\
\text { observed } \\
\text { assay (IU/1) }\end{array}$ & $\begin{array}{l}\text { Human } \\
\text { chorionic } \\
\text { gonado- } \\
\text { tropin } \\
\text { recovery } \\
(\%)\end{array}$ \\
\hline $\begin{array}{l}\text { Chemiluminescence assay } \\
\text { Serum A }\end{array}$ & 25.3 & & \\
$(14.5)$ & 123.1 & 22.3 & 88 \\
& 340.0 & 98.3 & 80 \\
Serum B & 25.1 & 291.1 & 85 \\
(20.8) & 113.4 & 22.6 & 90 \\
& 108.9 & 94.6 & 83 \\
Enzyme immunoassay & 290.8 & 94 \\
Serum B & 19.8 & & 102 \\
$(15.00)$ & 119.6 & 20.2 & 86 \\
& 340.6 & 102.5 & 82 \\
\hline
\end{tabular}

Carry-over

An important point during the human chorionic gonadotropin measurement in a routine laboratory is the possible carry-over from a high value sample to the next sample, which may be of lower concentration. In contrast to the ES-22 system, which has a carryover rate of about $0.9 \%(16)$, the Amerlite ${ }^{\circledR}$ system showed generally no carry-over, which was proved by placing diluent round sera with high human chorionic gonadotropin contents ( $>50000 \mathrm{IU} / \mathrm{l})$ in the microtitre plate. We looked especially at the washing procedure performed with the wash station; in the surrounding wells, containing only diluent, human chorionic gonadotropin was not detectable, either horizontally or vertically. The TECAN sample processor, however, was a potential source of such carry-over in connection with the chemiluminescence human cho- 
rionic gonadotropin measurement. But this problem could be minimized by special software adaptations of the liquid handling procedure (see under "Connection of the chemiluminescence assay ...").

\section{Specificity}

With the hypophyseal gonadotropins lutropin, follitropin and with thyrotropin in high serum concentrations, no appreciable cross-reactivities could be found in the chemiluminescence assay. Only one serum with high lutropin content showed a slightly raised human chorionic gonadotropin value with $2.3 \mathrm{IU} / 1$. These low rates of cross-reactivities are comparable with those obtained with the enzyme immunoassay. Results of the investigations of 5 sera are given in table 4 .

Tab. 4. Cross-reactivity of sera with high gonadotropin contents in the two compared immunoassays and crossreactivity of sera with endogeneous monoclonal antibodies in the chemiluminescence assay

\begin{tabular}{lcccll}
\hline Analyte & $\begin{array}{l}\text { Analyte } \\
\text { concentra- } \\
\text { tion }\end{array}$ & $\begin{array}{l}\text { Human chorionic } \\
\text { gonadotropin } \\
\text { concentration } \\
\text { determinated with }\end{array}$ \\
\cline { 2 - 6 } & & & $\begin{array}{l}\text { chemilumi- } \\
\text { nescence } \\
\text { assay }\end{array}$ & $\begin{array}{l}\text { enzyme } \\
\text { immuno- } \\
\text { assay }\end{array}$ \\
\hline Lutropin (serum 1) & $105 \mathrm{IU} / 1$ & $2.3 \mathrm{IU} / 1$ & - \\
Lutropin (serum 2) & $116 \mathrm{IU} / 1$ & $1.0 \mathrm{IU} / 1$ & - \\
Lutropin (serum 3) & $44 \mathrm{IU} / 1$ & $1.2 \mathrm{IU} / 1$ & $1.7 \mathrm{IU} / 1$ \\
Follitropin (serum 2) & $83.5 \mathrm{IU} / 1$ & $1.0 \mathrm{IU} / 1$ & - \\
Follitropin (serum 3) & $67.4 \mathrm{IU} / 1$ & $1.2 \mathrm{IU} / 1$ & $1.7 \mathrm{IU} / 1$ \\
Thyrotropin (serum 4) & $>80 \mathrm{mIU} / 1$ & $1.7 \mathrm{IU} / 1$ & - \\
Thyrotropin (serum 5) & $62 \mathrm{mIU} / 1$ & $0.3 \mathrm{IU} / 1$ & $0.8 \mathrm{IU} / 1$ \\
IgA-myeloma (serum 6) & $15.5 \mathrm{~g} / 1$ & $1.59 \mathrm{IU} / 1$ & - \\
IgG-myeloma (serum 7) & $10.5 \mathrm{~g} / 1$ & $<1.25 \mathrm{IU} / 1$ & - \\
IgG-myeloma (serum 8) & $18.7 \mathrm{~g} / \mathrm{l}$ & $1.38 \mathrm{IU} / 1$ & - \\
IgG-myeloma (serum 9) & $42.8 \mathrm{~g} / 1$ & $8.4 \mathrm{IU} / 1$ & - \\
\hline
\end{tabular}

No remarkable non-specific interferences of human chorionic gonadotropin determinations were found by measuring sera of patients with monoclonal gammopathies with high titres of certain immunoglobulins. Only one of these sera caused a minor falsepositive human chorionic gonadotropin result in the chemiluminescence assay, which is noted also in table 4 (serum 9). This outcome does not prove, of course, the ruggedness of the chemiluminescence assay against possible interferences with other heterophilic antibodies $(17,18)$.

Artificially haemolysed sera of several pregnant and non-pregnant women all gave correct results with the chemiluminescence assay (data not shown) and are comparable with those obtained with the routine assay. Lipaemic sera of pregnant and non-pregnant women all gave plausible positive or correct negative results with both immunoassays (data not shown). We did not investigate other effects like the high-dosehook effect or the prozone effect (19), because they are irrelevant for gynaecological questions.

\section{Method comparison}

\section{Method comparison of the chemiluminescence and the enzyme immunoassay}

Sera $(N=152)$ were measured in both assays. Besides the kit-controls, we used 3 external control sera and 1 pool serum in each run. Statistical evaluation was made according to the linear regression procedure given by Passing \& Bablok (20).

In the measuring range beyond $10000 \mathrm{IU} / \mathrm{l}$, determinations of human chorionic gonadotropin in two different assays are hardly comparable because of dilutions of a different kind. We decided therefore to split the statistical evaluation (fig. $3 \mathrm{a}-\mathrm{c}$ ). In the range up to $1000 \mathrm{IU} / 1$ the two compared immunoassays show high coefficients of correlation.

Method comparison of the chemiluminescence assays human chorionic gonadotropin-60 and human chorionic gonadotropin-15

In the same way we compared the short version of the chemiluminescence assay for human chorionic gonadotropin (incubation time $15 \mathrm{~min}$ ) with the 60 min version (figures $4 a, b$ ). Since the incubation period was so short, only a maximum of 4 strips of antibody coated wells instead of 8 were performed because of the time delay caused by pipetting steps. The coefficients of correlation show good agreement.

\section{Over-all assay handling}

The practicability of the chemiluminescence kit was comparable with the enzyme immunoassay with respect to the special requirements of a routine laboratory: simple handling and convenience, application of ready-to-use reagents, informative computer protocol of results including raw data and perfected instrumentation units. Regarding the flexibility of the assay, the Amerlite ${ }^{\circledR}$ system has several advantages. The total assay-time is slightly shorter in the chemiluminescence system (about 135 minutes for 30 human chorionic gonadotropin determinations), but the hands-on-times are comparable in both assays. The flexibility of the new assay system can further be 

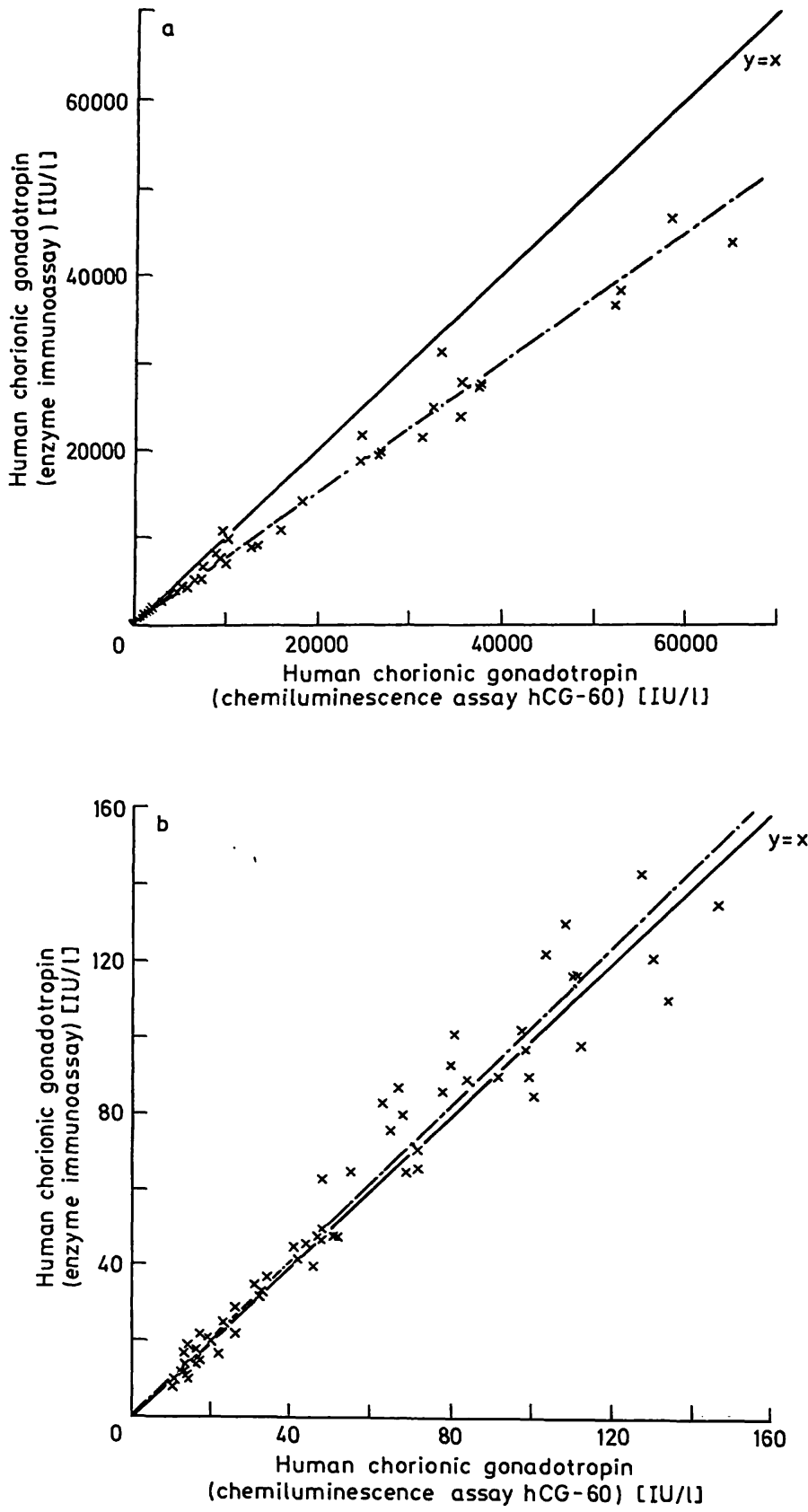

raised by implementing the TECAN robotic sample processor, optional with on-line integration in the laboratory computer system enabling computer assisted down-loading of requested tests and with direct sample identification by a barcode reader.

Connection of the chemiluminescence assay system with the TECAN robotic sample processor

To accelerate and facilitate sample handling we connected the new assay system with the robotic sample processor TECAN RSP 5402. This is a dual-arm sample processor for automatic liquid pipetting of immunoassays. The two arms may be used in conjunction or independently to carry out programmed operations. Our aim was to create a pipetting program

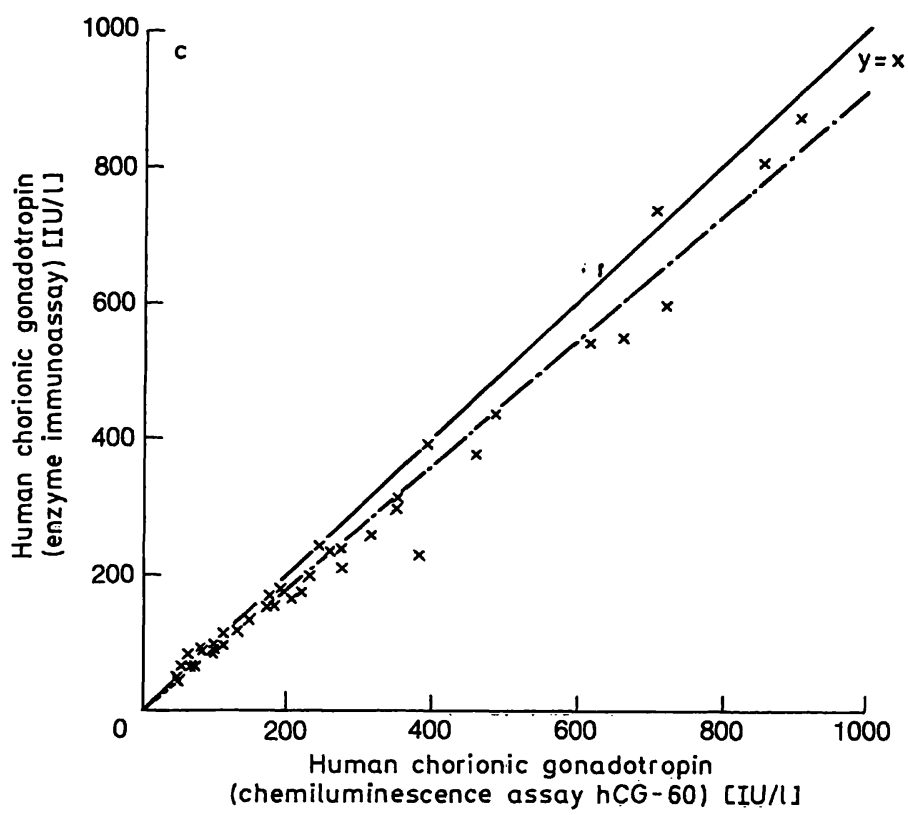

Fig. 3. Method comparison of the chemiluminescence and the enzyme immunoassay

a) Measuring range: $0-70000 \mathrm{IU} / 1$, number of paired values: 152 , $\mathrm{y}=0.773 \mathrm{x}+111.5$ coefficient of correlation: 0.995

b) Measuring range: $0-150 \mathrm{IU} / \mathrm{l}$, number of paired values: 68 , $\mathrm{y}=1.019 \mathrm{x}+0.516$ coefficient of correlation: $\mathbf{0 . 9 7 6}$

c) Measuring range: $50-1.000 \mathrm{IU} / 1$, number of paired values: 44 , $\mathrm{y}=0.921 \mathrm{x}-0.811$ coefficient of correlation: 0.990

permitting both high performance sample distribution and minimization of serum contaminations.

Several precautions against carry-over were implemented for the TECAN processor by the manufacturer: teflonized tips, built-in liquid level detectors to prevent over-immersion of tips and special wash stations for rinsing tips inside and out between operations.

Nevertheless we saw carry-over rates of about $0.01-$ $0.05 \%$ in pilot studies, according to a formula for the carry-over rate given by Singer et al. (14). The possible juxtaposition of unknown samples with highly different human chorionic gonadotropin contents made such carry-over rates unacceptable.for us. Therefore the control software was optimized for the special 

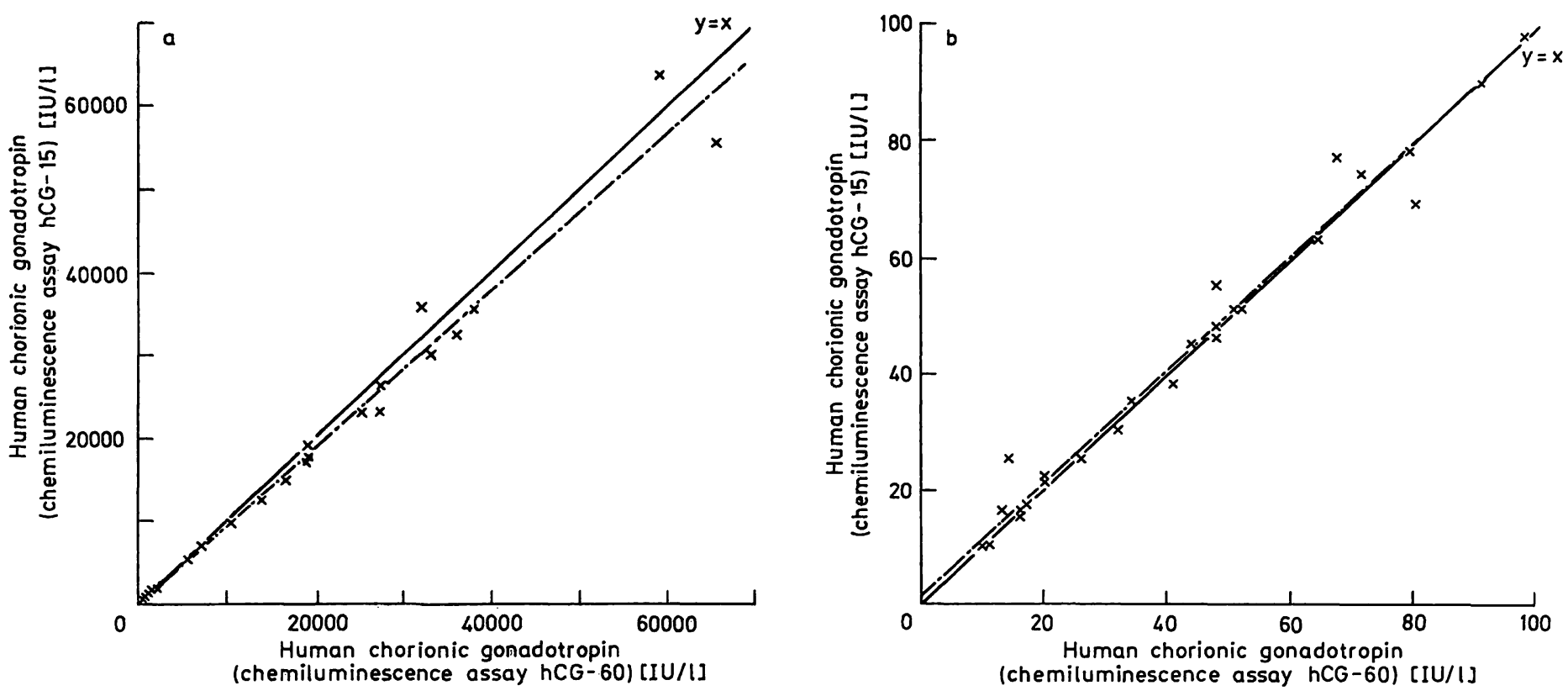

Fig. 4. Method comparison of the human chorionic gonadotropin-60 and human chorionic gonadotropin-15 versions of the chemiluminescence assay

a) Measuring range: $9-70000 \mathrm{IU} / 1$, number of paired values: 62 , $y=0.941 x-45.1$ coefficient of correlation: 0.994

b) Measuring range: $0-100 \mathrm{IU} / \mathrm{l}$, number of paired values: 28, $y=0.969 x+1.549$ coefficient of correlation: 0.989
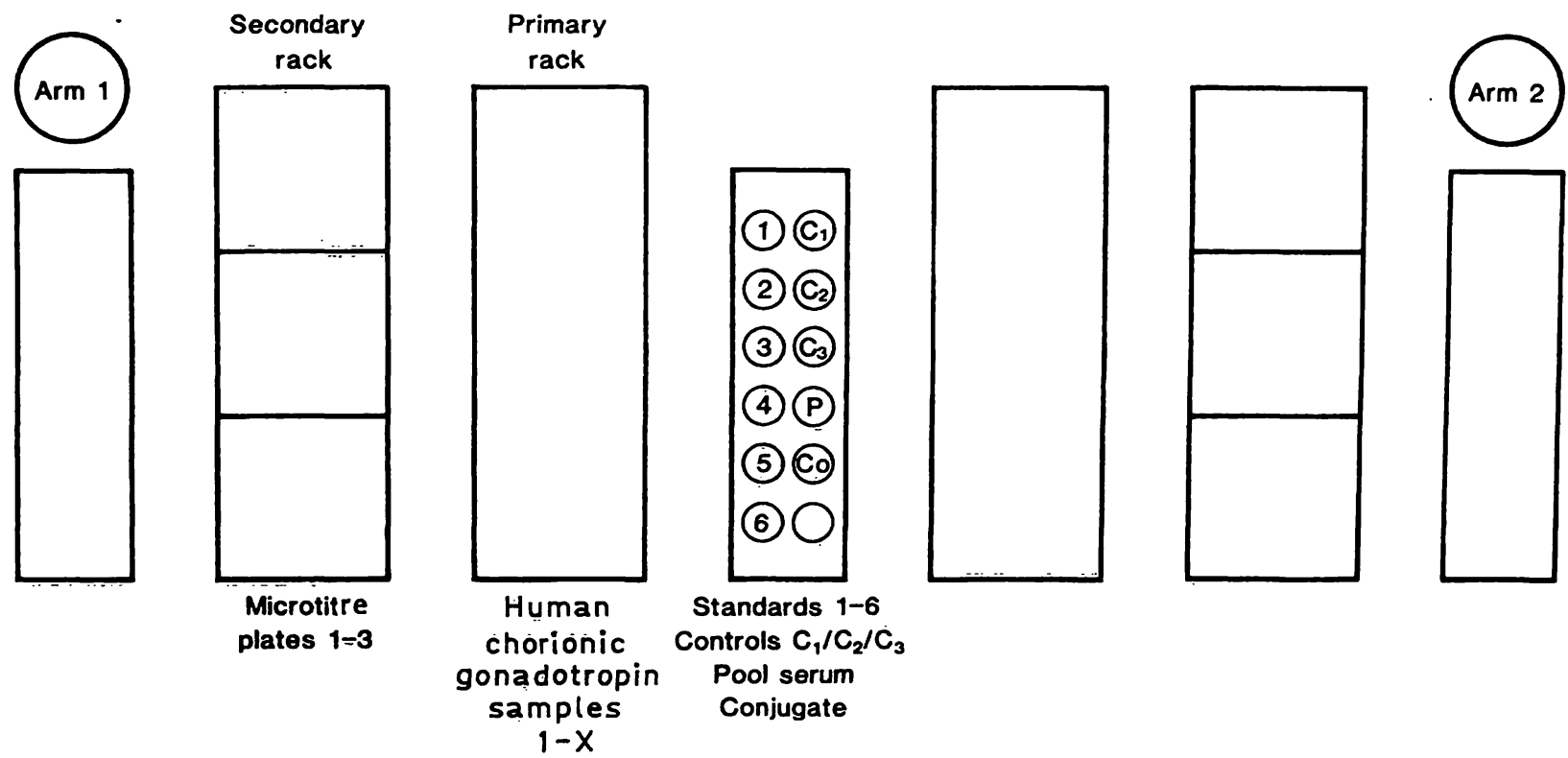

Fig. 5. Layout of the distribution of human chorionic gonadotropin samples with the TECAN sample processor

requirements of fast distribution combined with minimized contamination: after each duplicate sample distribution tips first drive to a waste position, where serum residues are ejected with $800 \mu$ of distilled water. Only then, the arms are directed to the inner wash station, where tips are washed around with another $2000 \mu \mathrm{l}$ water. Carry-over is thereby reduced to less than $0.005 \%$. This procedure is time-consum- ing. For this reason, it is only programmed for the distribution of samples, not for the distribution of standards or conjugate. In addition the time delay of this mode of operation is compensated through the choice of a simultaneous two-arm configuration of the robotic sample processor. The two single arms work together simultaneously, first for multi-pipetting conjugate to the microtitre plates, and then for pi- 
petting sera. For duplicates both arms distribute one sample temporarily interlocked from the primary tube to the two secondary tubes. In figure 5 the layout for the sample processing is illustrated. The pipetting of 30 sera including standards, 3 control sera, 1 pool serum arranged in replicates after 10 samples respectively and multi-pipetting of conjugate into each well requires a total of 21 minutes.

\section{Discussion}

The aim of this study was to determine whether a new two-site immunoassay system produces comparable or better performance data than our routine enzyme immunoassay. We stipulated several special requirements for the novel assay: good precision and reliability data, no susceptibility to interferences, good correlation with the former assay, short assay time, easy handling and flexibility, possible automation and effortless integration in the laboratory.

Evaluating 152 pregnancy sera, we found that the enhanced chemiluminescence assay for human chorionic gonadotropin has a good practicability with respect to the above mentioned criteria: the withinseries and between-series precisions are good with variation coefficients of 3 and $5 \%$ on average. The assay has a wide working range; the lower detection limit and the linearity are excellent. Recovery was satisfactory at $86 \%$ on average. The cross-reactivity measurements point to the excellent specificities of the employed antibodies. Remarkable interferences through immunoglobulins in patients with monoclonal gammopathies could not be detected. Possible interferences through heterophilic antibodies, recently reviewed by Boscato \& Stuart (18), did not appear during our investigation.

The printout of results is satisfactory with respect to clarity, presentation of data and raw data from the microtitre plate. Also enclosed with the program is a quality control memory for three eligible control sera. In general the chemiluminescence assay system permits a very effective handling, and the reagents have a long shelf life.

The method comparison with the enzyme immunoassay demonstrates the comparability of results. The coefficients of correlation (r) vary between 0.976 and 0.995 . In the upper range, however, the chemiluminescence assay shows slightly lower chorionic gonadotropin values, but in the important diagnostic range between 50 and $1000 \mathrm{IU} / 1$ the correlation coefficient $(r=0.990)$ is satisfactory. Since ectopic pregnancies are often a cause of acute gynaecologic emergency situations, flexibility is of pivotal importance in the judgement of a human chorionic gonadotropin assay used in a clinical chemistry laboratory. From this piont of view the chemiluminescence assay system offers a remarkable advantage compared with the modular batch ELISA system. Because of its short incubation time and the possibility of adaptable length of the microtitre strips together with a very short measuring time (within 2 minutes) the assay format gains high flexibility. Additionally the correlation of the $15 \mathrm{~min}$ version to the normal $60 \mathrm{~min}$ version of the chemiluminescence assay is remarkable. Another advantage is the total absence of carry-over within assay runs pursuant to the configuration of the assay format.

The absence of automation, an undeniable disadvantage of the Amerlite ${ }^{\circledR}$ compared with the ES-22 system, can be compensated by use of an automatic sample processor. We applied the dual-arm processor TECAN RSP 5402. With specially adapted software programs we optimized sample handling, resulting in an adequate distribution rate combined with minimized carry-over (below $0.005 \%$ ). In this way the total assay times are shorter with this system compared with the modular batch analyser system for the performance of the enzyme immunoassay.

\section{Conclusion}

The new chemiluminescence assay for human chorionic gonadotropin in connection with the TECAN RSP 5402 processor is an advanced and versatile system for the determination of human chorionic gonadotropin in laboratories with high daily sample numbers. The assay is rapid, simple to handle and without detected susceptibility to interferences. Total assay times with the Amerlite ${ }^{\circledR}$ and the ES-22 system are comparable, but the Amerlite ${ }^{\circledR}$ human chorionic gonadotropin assay can also be performed in a short version. In addition the enhanced chemiluminescence assay system offers the advantages of a flexible multibatch analyser; the possibility of parallel test performances within gynaecological analytes like lutropin, follitropin or prolactin indicates the suitability of the system in the gynaecological unit of a clinical chemistry department.

\section{Acknowledgement}

We are grateful to Amersham-Buchler GmbH \& Co $\mathrm{KG}$, Braunschweig, for the supply of human chorionic gonadotropin-60 kits and to Mrs. A. de Haas, Zinsser Analytic, for her help in setting up the sample processor software.

Thanks are also due to Mrs. B. Flemmig and Mrs. U. Langmandel for their expert technical assistariöe. 


\section{References}

1. Vaitukaitis, J. L. (1979) N. Engl. J. Med. 301, 324-326.

2. Ozturk, M., Bellet, D., Manil, L., Hennen, G., Frydman, R. \& Wands, J. (1987) Endocrinology 120, 549-558.

3. Norman, R. J., Haneef, R., Buck, R. H. \& Joubert, S. M: (1987) Clin. Chem. 33, 1147-1151.

4. Norman, R. J., Lowings, C., Oliver, T. \& Chard, T. (1985) Clin. Endocrinol. 23, 25-34.

5. Mann, K., Lamerz, R., Hellmann, T., Kümper, H. J., Staehler, G. \& Karl, H. J. (1980) Oncodev. Biol. Med. 1, $301-$ 312.

6. Romero, R., Kadar, N., Copel, J. A., Jeanty, P., DeCherney, A. H. \& Hobbins, J. C. (1986) Am. J. Obstet. Gynecol. $155,392-394$.

7. Kadar, N., Caldwell, B. V. \& Romero, R. (1981) Obstet. Gynecol. 58, 162-166.

8. Strasburger, C. J., Fricke, H., Gadow, A., Klingler, W. \& Wood, W. G. (1983) Ärztl. Lab. 29, 75-82.

9. Wood, W. G. (1984) Labo 15, 1287-1292.

10. Klingler, W., Strasburger, D. J. \& Wood, W. G. (1983) Trends Anal. Chem. 2, 132-136.

11. Thorpe, G. H. G., Kricka, L. J., Moseley, S. B. \& Whitehead, T. P. (1985) Clin. Chem. 31, 1335-1341.
12. Thorpe, G. H. G., Moseley, S. B., Kricka, L. J., Scott, R. A. \& Whitehead, T. P. (1985) Anal. Chim. Acta 170, 101 107.

13. Spiller, G., Tovey, K. C., Smith, G. S. W. \& Mashiter, K. (1986) Poster presented at the AACC Meeting, Chicago 1986.

14. Singer, R., Clarke, S. F., Crafter, V. A., Gray, B. C., Kilshaw, D., Randell, J. A., Robinson, J. L. \& White, J. M. (1987) Med. Lab. Sci. 44, 6-14.

15. Klee, G. G. \& Hay, I. D. (1987) J. Clin. Endocrinol. Metabol. 64, 461-472.

16. Meyer, H. D. \& Braun, S. L. (1985) Ärztl. Lab. 31, $308-$ 312.

17. Check, J. H., Nowroozi, K., Chase, J. S., Lauer, C., Elkins, B. \& Wu, C. H. (1988) Am. J. Obstet. Gynecol. 158, 99100.

18. Boscato, L. M. \& Stuart, M. C. (1988) Clin. Chem. 34, 27-33.

19. Gelletlie, R. \& Nielsen, J. B. (1986) Clin. Chem. 32, $2166-$ 2170.

20. Passing, H. \& Bablok, W. (1983) J. Clin. Chem. Clin. Biochem. 21, 709-720.

Dr. med. Peter Luppa

Institut für Klinische Chemie am Klinikum Großhadern

Marchioninistraße 15

D-8000 München 70 
